\title{
DEVONIAN TENTACULITOIDEA OF PONTA GROSSA FORMATION, PARANÁ BASIN: DESCRIPTION AND SOME TAPHONOMIC ASPECTS
}

\author{
MARCELA MEDEROS FREGATTO \& CRISTINA SILVEIRA VEGA \\ Centro Politécnico, Departamento de Geologia, Setor de Ciências da Terra, UFPR, Cx. P. 19001, 81531-980, \\ Curitiba, PR, Brazil.fregattomf@gmail.com,cvega@ufpr.br
}

\begin{abstract}
Tentaculitoidea is an extinct invertebrate group, being recorded from Ordovician to Devonian. The group is identified by a small conical shell, millimetric sized, opened at one of the extremities and composed by calcium carbonate. The aim of this research is to identify Tentaculitoidea molluscs deposited in the collection of the Paleontology Laboratory, Sector of Earth Sciences, at Universidade Federal do Paraná, and also contribute to increase of knowledge concerning this fossil group. Most representative specimens were selected from 317 rock samples containing 1882 specimens. The samples came from the Ponta Grossa Formation (Early Devonian-Late Devonian), more specifically from the members Jaguariaíva and São Domingos. There were identified five genera, as Homoctenus, Seretites jaculus, Styliolina, Tentaculites and Uniconus. It was possible to conclude that, in the LabPaleo, the predominant genus is Homoctenus, and Jaguariaíva Member contains more samples with tentaculitoid than São Domingos Member, although this fact can be attributed to the sampling bias. Unfortunately, due to the poor preservation of shell, many specimens could not be identified.
\end{abstract}

Key words: Tentaculitoidea, Paraná Basin, Devonian, Ponta Grossa Formation.

RESUMO - Tentaculitoidea corresponde a um grupo de invertebrados extintos, sendo registrados do Ordoviciano ao Devoniano. O grupo é identificado por uma concha pequena e cônica, de tamanho milimétrico, aberta em uma das extremidades, e composta por carbonato de cálcio. O objetivo deste trabalho é identificar os moluscos Tentaculitoidea depositados na coleção do Laboratório de Paleontologia do Setor de Ciências da Terra, na Universidade Federal do Paraná, bem como contribuir com o conhecimento acerca deste grupo fóssil. Para tanto, foram selecionados os espécimes mais representativos, correspondendo a um total de 317 amostras rochosas contendo 1882 espécimes. As amostras são procedentes da Formação Ponta Grossa (Eo-Neodevoniano), mais especificamente dos membros Jaguariaíva e São Domingos. Foram identificados cinco gêneros, Homoctenus, Seretites jaculus, Styliolina, Tentaculites e Uniconus. Foi possível concluir que na coleção científica estudada, o gênero predominante é Homoctenus, e que no Membro Jaguariaíva há mais amostras de tentaculitoideos que no Membro São Domingos, embora isto possa ser atribuído a um artefato de amostragem durante a coleta. Infelizmente, devido ao estado precário de preservação das conchas, muitos espécimes não puderam ser identificados.

Palavras-chave: Tentaculitoidea, bacia do Paraná, Devoniano, Formação Ponta Grossa.

\section{INTRODUCTION}

Tentaculitoids are an extinct group of marine invertebrates that occur in Silurian and Devonian times. Over the past decades, they have been referred to several phyla, but with no convincing evidence. Nevertheless, there are currently two distinct ideas: i) tentaculitoids is an independent class affiliated or related to the phylum Mollusca due to the resemblance in shell morphology and wall structure (Fisher, 1962; Mendes, 1965; Blind, 1969; Ciguel, 1989; Brassel et al., 1971; Wei et al., 2012); ii) tentaculitoids is a close-related group of microconchids and cornulitids (Weedon, 1990, 1991; Vinn \& Mutvei, 2005; Vinn \& Taylor, 2007; Vinn et al., 2008; Zatón \& Taylor, 2009; Vinn \& Mutvei, 2009; Vinn, 2010; Vinn \& Zatoń, 2012). They may share affinities with lophophorates (Towe, 1978; Larsson, 1979) as tentaculitoids and microconchids (i.e. possible lophophorates) are very similar in their wall microstructure, including micro-lamellar layers, pseudopuncta and cross-bladed fabric.

Tentaculitoids provide a good source for biogeographic and stratigraphic studies. Alberti (1993, cited by Wei et al., 2012) described the global distribution of several thin-walled tentaculitoid genera and species from the Lochkovian to the Eifelian. Thereafter, Wittmer \& Miller (2011) analyzed the global diversity trends of tentaculitoids based on their global geographic distribution from the Ordovician to the Devonian. The use of planktonic tentaculitids for stratigraphy has resulted in the recognition of their importance for biostratigraphy. $\mathrm{Li}$ (2000) also presented stratigraphic correlations between tentaculitoids and conodonts. Major contributions result from the work of Alberti $(1982,2000)$. According to Wei et al. (2012), tentaculitoid abundance varied noticeably during the Silurian and Devonian, which is delineated by: i) the stratigraphic distribution at the level of genus; ii) the number 
of associations reported; iii) the primary latitudinal range of the group for each geological age.

Amongst the fossils that occur in Ponta Grossa Formation, tentaculitoids are one of the most abundant (Bond, 2006) and occur frequently associated with each other and with other fossil groups. According to Ciguel (1989), the class Tentaculitoidea Lyashenko (1957) (= Cricoconarida by Fisher, 1962) (Bond, 2006) members are not confined to a particular facies or a faunistic association. They occur both in foreshore and offshore facies. The tentaculitoids are identified by a small, mm sized, conical shell and characteristic ornamentation. In South America, the group has a wide paleogeographic distribution, suggesting that the dispersion between Ordovician and Devonian was efficient. In Paraná Basin, they occur mainly in Ponta Grossa Formation, as external and internal molds. Ciguel et al. (1987) discovered a partial preservation of a single shell of Tentaculites crotalinus in the aforementioned formation, which is unusual because no other preserved shells were published in Paraná Basin.

Tentaculitoids were abundant, especially in Early Devonian, when they attained their maximum geographic distribution (Ciguel, 1989). The Devonian brought about three major changes amongst these organisms: a marked growth in the number of associations, a major geographical expansion, and a reshuffling of dominances among the tentaculitoid genera with the emergence of dacryoconarids and homoctenids. The Late Devonian tentaculitoids show a notable decrease in geographic extent and number of associations, followed by a progressive decline until their extinction in the Famennian (Wei et al., 2012). Richest records of Devonian tentaculitoids are related to sea transgressions followed by regressions; such events are usually global in nature (Bosetti et al., 2011).

The stratigraphic scheme adopted here was proposed by Milani et al. $(1994,2007)$ and was selected because studied material has been catalogued following those authors. Nevertheless, Grahn et al. (2010), based on integrated palynological age determination, proposes the change of São Domingos Member to the Formation rank and the extinction of the Jaguariaíva Member, keeping the stratigraphic interval named as Lower Ponta Grossa Formation.

In Ponta Grossa Formation, from Paraná Basin, seven different genera were identified by Ciguel (1989): Tentaculites, Styliolina, Seretites, Uniconus, Homoctenus, Paranowakia, Vmitriella. Azevedo-Soares (1999) made a systematic revision of the Tentaculitoidea's Class from the Ponta Grossa Formation. However, only two specimens were identified: Tentaculites crotalinus and T.jaculus, due to their unsatisfactory preservation as incomplete molds. Additionally, there are some peculiarities in the Malvinocaffric Realm, as the environment imposed a low taxonomic diversity in the marine fauna. This state differs from the more diversified and richer carbonate provinces that occur in the northern hemisphere, where the carbonate rocks allowed a better preservation of the tentaculitoids, enabling detail study of the shell morphology. Such detailed study is not possible in case of the shale and mudstone samples from Ponta Grossa Formation, since they are extremely poorly preserved.
Although the specimens studied here are also poorly preserved, they could be classified following Ciguel (1989).

Through the analysis and classification of the tentaculitoids specimens deposited in the collection of the Paleontology Laboratory, Universidade Federal do Paraná, we have obtained results concerning the generic distribution of these organisms on the Ponta Grossa Formation.

\section{MATERIAL AND METHODS}

The fossils were analyzed as they were deposited in the collection, without further preparation. Each fossil was described using a stereomicroscope (Olympus SZ40) under several magnifications, in order to observe ornamentation details, morphotype and shell's mold morphology. The laboratory procedures are based on Ciguel (1989), Schenk \& McMasters (1956), Simpson (1962), Raup \& Stanley (1978), Ljaschenko (1955) and Hajlasz (1967), as follows: (i) selection of the samples in the collection based on the state of preservation; (ii) identification of taxa; (iii) interpretation and (iv) conclusions about affinities and/ or differences. All tentaculitoid samples deposited in the Collection of the Paleontology Laboratory (LabPaleo), Earth Sciences Department, Universidade Federal do Paraná (UFPR) were described, containing 317 samples and 1882 specimens that came from different outcrops of the Ponta Grossa Formation (Eodevonian-Neodevonian), Jaguariaíva and São Domingos members (Figure 1). These samples were analyzed and classified; the most representative specimens of each genus were selected, photographed and described. Each described sample was registered on a spreadsheet, according to their registration number (UFPR 0000 PI), genus and number of specimens per sample. UFPR stands for the institution where the materials were deposited and PI means Invertebrate Paleontology. The samples used for comparison where registered as NR 000, considering the registration applied to didactic collection. Unfortunately, different student groups collected the studied material during several trips to the field and without stratigraphic data, precluding advanced stratigraphic studies. The samples came from three different outcrops from the Ponta Grossa Formation, as follow: Rio Caniú outcrop (Ponta Grossa: Palmeira road, PR 151, km 365,5, coordinates $25^{\circ} 18^{\prime} 48^{\prime \prime} \mathrm{S}, 49^{\circ} 39^{\prime} 26^{\prime \prime} \mathrm{W}$ ); Aeroporto Sant'Ana outcrop (Ponta Grossa: Palmeira road, PR 151, viaduct over railroad, coordinates $25^{\circ} 10^{\prime} 48^{\prime \prime} \mathrm{S}$, $50^{\circ} 08^{\prime} 47^{\prime \prime} \mathrm{W}$ ) and Jaguariaíva outcrop (Jaguariaíva: Arapoti railroad, between $\mathrm{km} 0,5$ and 6,2 , coordinates $24^{\circ} 14^{\prime} 50^{\prime \prime} \mathrm{S}$, 4943'18”W) (Azevedo et al., 2002).

\section{RESULTS}

In this study we were able to identify five genera: Tentaculites, Homoctenus, Uniconus, Styliolina and Seretites (Figure 2). All the samples (1882 studied specimens) were classified and grouped in the Appendix 1. The description of the most representative specimens as well as their pictures and drawings are stated below. 


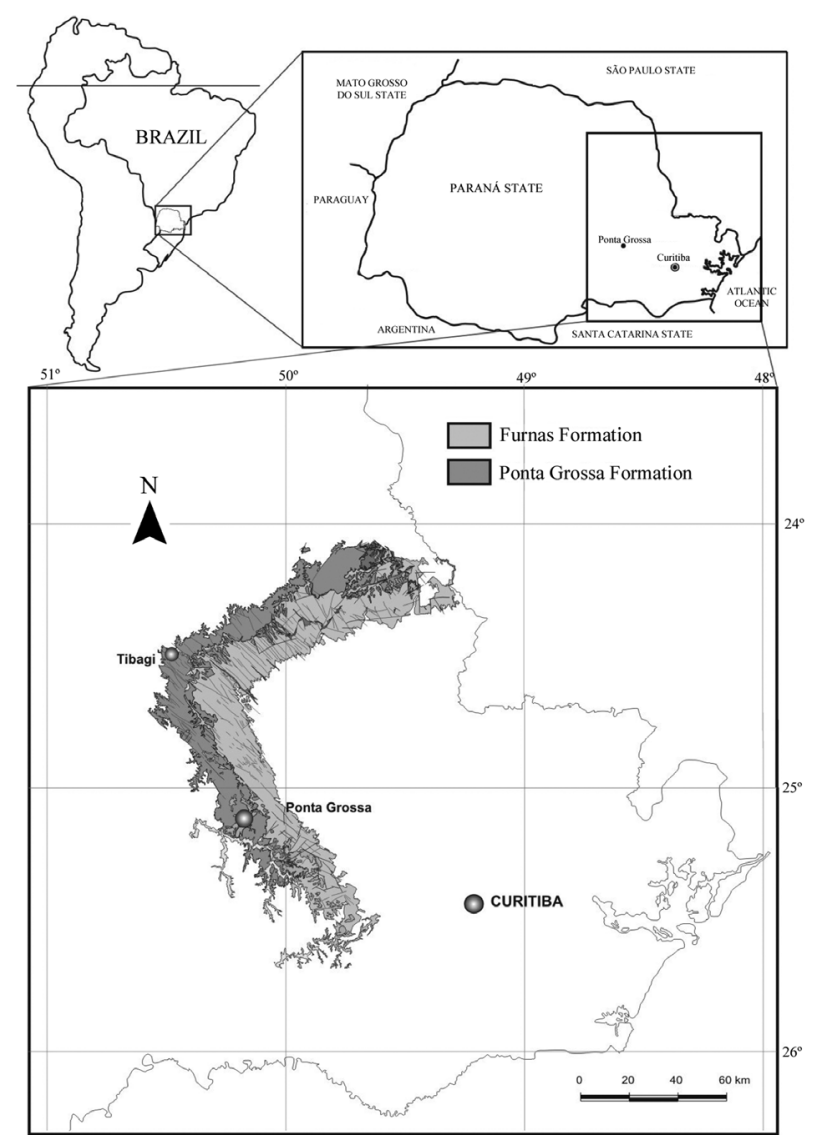

Figure 1. Map of the studied area with identification of the collection points. The outcrop Jaguariaíva belongs to Jaguariaíva Member and both the outcrops Aeroporto Sant'Ana and Rio Caniú belong to São Domingos Member. Modified from Bosetti et al. (2007).

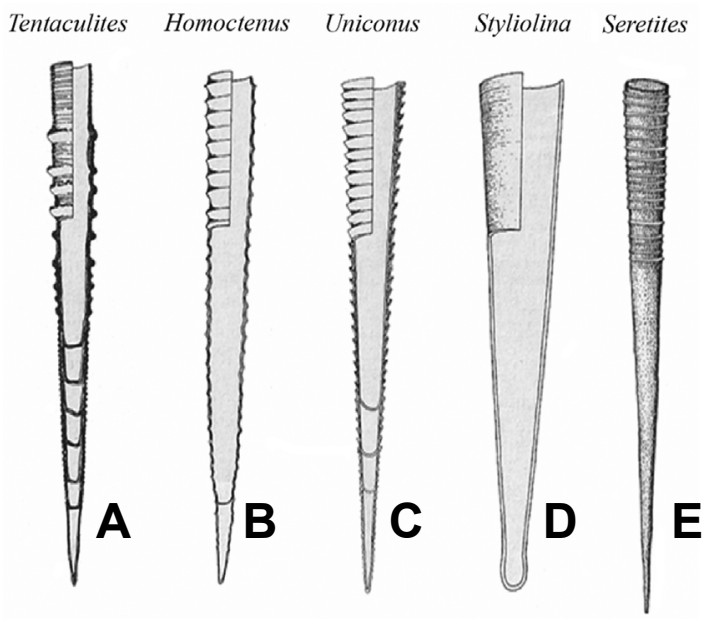

Figure 2. Identified genus of Tentaculitoidea. A, Tentaculites; B, Homoctenus; C, Uniconus; D, Styliolina; E, Seretites. Modified from Fisher (1962) and Ciguel et al. (1984). No scale.

Order TENTACULITOIDEA Ljaschenko, 1957 Family TENTACULITOIDAE Walcott, 1886

Tentaculites Schlotheim, 1820

(Figures 3A-C)
From the 1882 studied specimens, 171 belong to the genus Tentaculites.

Material. UFPR 0111 PI (Figure 3A), UFPR 0113 PI (Figure 3B) and UFPR 0112 PI (Figure 3C).

Outcrop. Jaguariaíva, Jaguariaíva Member. UFPR 0112 PI is from an unspecified outcrop.

Description. conic shells, ornamented with transversal rings, with a wispy uniform thickening. The external mold is preserved. Inter-ring area formed by microrings, which can be better observed with a stereomicroscope. The inter-ring spaces are deep, tenuously concave, with maximum length of $0.5 \mathrm{~mm}$. The most notable feature of the genus is the presence of microrings in the inter-ring zone, which is confirmed by Fisher (1962) and Ciguel (1989).

Specific characteristics. UFPR 0111 PI: maximum length $=18$ $\mathrm{mm}$; maximum diameter $=2.5 \mathrm{~mm} ; 9-14$ perpendicular rings per $4 \mathrm{~mm}$. UFPR $0113 \mathrm{PI}$ : maximum length $=11 \mathrm{~mm}$; maximum diameter $=1.5 \mathrm{~mm}$; 10-11 rings per $4 \mathrm{~mm}$. UFPR $0112 \mathrm{PI}$ : maximum length $=16 \mathrm{~mm}$; maximum diameter $=1.9 \mathrm{~mm}$; $7-8$ rings per $4 \mathrm{~mm}$.

Seretites Lyashenko, 1969

Seretites jaculus Clarke, 1913

(Figure 3D)

Material. Three specimens. UFPR 0114 PI (Figure 3D). Outcrop. Aeroporto Sant'Ana, São Domingos Member. Description. Conical shell, ornated with symmetrical, rounded, expressionless and similar transversal rings only in the proximal zone and in the middle zone. The external mold is preserved. Maximum length $=25 \mathrm{~mm}$; maximum diameter $=2.7 \mathrm{~mm}$; 16 rings per $4 \mathrm{~mm}$. Inter-ring spaces: inconstant length, shallow, tenuously concave to flat, maximum length $=0.3$ $\mathrm{mm}$. The shell has a conical and abrupt intial chamber, the rings abruptly arise on the late third part of the shell. The most notable feature of the genus is a half smooth and half ornamented shell, which is confirmed by Ciguel (1989).

Order HOMOCTENIDA Boucek, 1964 Family HOMOCTENIDAE Lyashenko, 1955

Homoctenus Lyashenko, 1955

(Figures 3E,F)

Material. 213 specimens. UFPR 0115 PI (Figure 3E) and UFPR 0125 PI (Figure 3F).

Outcrop. Jaguariaíva, Jaguariaíva Member.

Description. Conical shells, straight, ornated with symmetrical, angular, well developed and similar transversal rings increasing in size proportionally with growth. Only the external molds are preserved. Microrings can be observed in the proximal part of the shell. Both shells present a conical and abrupt intial chamber. The most notable feature of the genus is the pronounced and angular shell's rings with large concavities between them, which is confirmed by Fisher (1962) and Ciguel (1989). 
Specific characteristics. UFPR 0115 PI: maximum length $=25 \mathrm{~mm}$; maximum diameter $=2.3 \mathrm{~mm} ; 6-7$ rings per $4 \mathrm{~mm}$; maximum inter-ring length $=1.6 \mathrm{~mm}$. UFPR 0125 PI: maximum length $=14 \mathrm{~mm}$; maximum diameter $=1 \mathrm{~mm}$; 16-17 rings per $4 \mathrm{~mm}$; maximum inter-ring length $=0.2 \mathrm{~mm}$.

\section{Family UNICONIDAE Lyashenko, 1955}

Uniconus Lyashenko, 1955

(Figure 3G)

Material. 66 specimens. UFPR 0116 PI (Figure 3G).

Outcrop. Aeroporto Sant'Ana, São Domingos Member.

Description. Small conical shell, with pyritization in the proximal zone, which caused the poor preservation of the ornamentation. The shell is straight, ornated with asymmetrical, angular, well-developed and similar transversal rings, which increase in size proportionally with shell growth. The internal mold is preserved. Maximum length $=11 \mathrm{~mm}$; maximum diameter $=1.3 \mathrm{~mm} ; 19$ rings per $4 \mathrm{~mm}$; maximum inter-ring length $=0.3 \mathrm{~mm}$, the spaces are smooth and regularly spaced. The most notable feature of the genus is the shell's asymmetrical rings with extremities oriented towards the proximal zone, which is confirmed by Fisher (1962) and Ciguel (1989).

\section{Order DACRYOCONARIDA Fisher, 1962}

Family STYLIOLINIDAE Grabau, 1912

Styliolina Karpinsky, 1884

(Figure 3H)

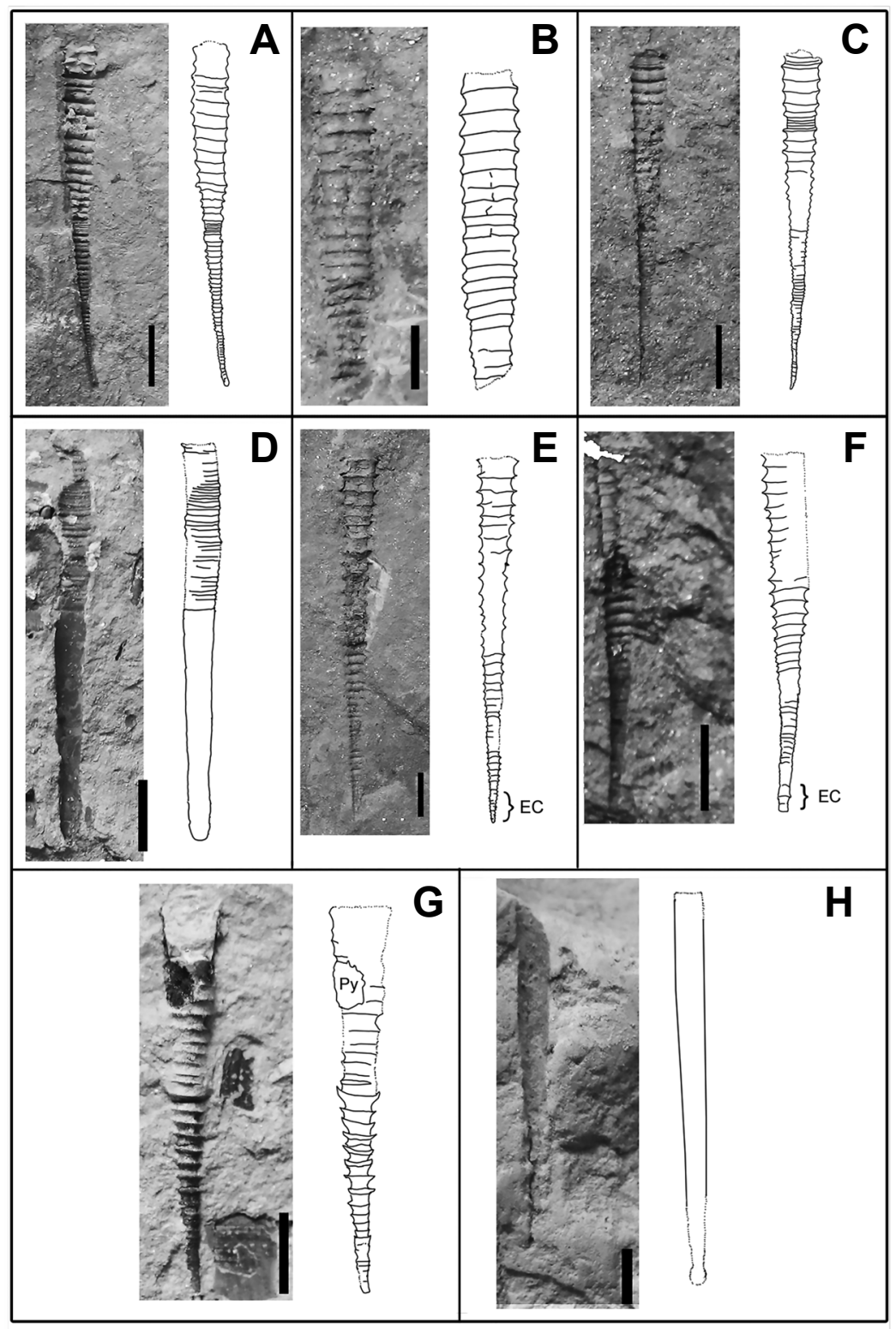

Figure 3. Tentaculitids from the Ponta Grossa Formation, photos and drawings. A-C, Tentaculites (UFPR 0111 PI, UFPR 0113 PI and UFPR 0112 PI, respectively). D, Seretites jaculus (UFPR 0114 PI). E, F, Homoctenus (UFPR 0115 PI and UFPR 0125 PI, respectively). G, Uniconus (UFPR 0116 PI). H, Styliolina (UFPR 0117 PI). Abbreviations: EC, intial chamber; Py, pyrite. Scale bars: A, C, E-F, H= 3 mm; B, G = 2 mm; D = 4 mm. 
Material. UFPR 0117 PI (Figure 3H).

Outcrop. Unidentified, from Ponta Grossa Formation.

Description. Conical shell, straight and smooth. The external mold is preserved. Maximum length= $20 \mathrm{~mm}$; maximum diameter $=2.2 \mathrm{~mm}$. The intial chamber has a droplet shape and an abrupt apex. The most notable feature of the genus is the absence of shell's ornamentation, which is confirmed by Fisher (1962) and Ciguel (1989).

\section{DISCUSSION}

The description of samples allowed the identification of some taphonomic aspects. Since the classification of those organisms is based on the shell's ornamentation, it is necessary to have a satisfactory preservation to properly identify them.

Some specimens have a completely smooth shell due to weathering. Such cases can easily cause confusion because some genera like Styliolina, characterized by the absence of rings. Therefore, for a correct identification, is necessary to look for transverse strias in the shell's external mold. The same applies to partial external molds or fragmented shells, because the preservation of only a proximal zone from an external mold that contains for example macro and micro rings could be identified as Homoctenus or Seretites jaculus, very distinct genus when the individuals are completely preserved.

In the universe of 1882 samples, 1438 could not be identified due to fragmented shells and high abrasion levels. Some samples are pyritized (Figure 4), and although such mineralization preserves the external and internal molds, the ornamentation can not be observed, which precludes the correct sample identification. Some shells are longitudinally fractured at the middle zone, probably due to the sediment compression and diagenesis (Figure 5). Such fractures can easily be confused with the longitudinal stria, as these belongs to the original morphology of many tentaculitoids.

Azevedo-Soares (1999) concluded that most of the specimens from Ponta Grossa Formation do not show a preferential paleodirection of water flow, except for the specimens from Jaguariaíva Member. However, occurrences of tentaculitoid groups have been observed, and often these show a main orientation, which indicates an unidirectional paleocurrent (Figure 6). Future works must consider this information during field works, then these data can be used to paleocurrent and paleoenvironment studies. Another interesting aspect is that tentaculitoid samples are often preserved in association with other groups of organisms, such as brachiopods (Figure 7). This fact suggests that those organisms shared the same environment and can help in to paleoenvironment reconstitutions, although facies and structural data must be considered to corroborate this hypothesis.

A total of 317 samples were studied containing 1882 specimens; 174 samples, with 777 tentaculitoids, belonged to Jaguariaíva Member and 60 samples, containing 623 specimens, belonged to São Domingos Member (Figure 8; Table 1). Still, there are 73 samples, with 482 individuals, which lack the exact outcrop.

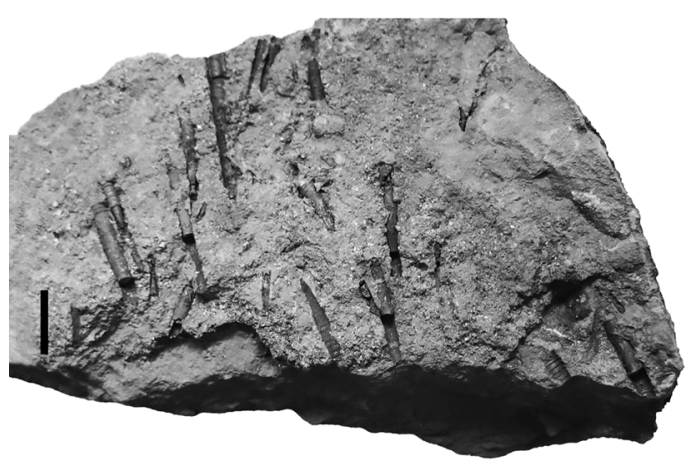

Figure 4. Pyritized sample (UFPR $0118 \mathrm{PI}$ ), unidentified tentaculitoid genus. Scale bar $=6 \mathrm{~mm}$.

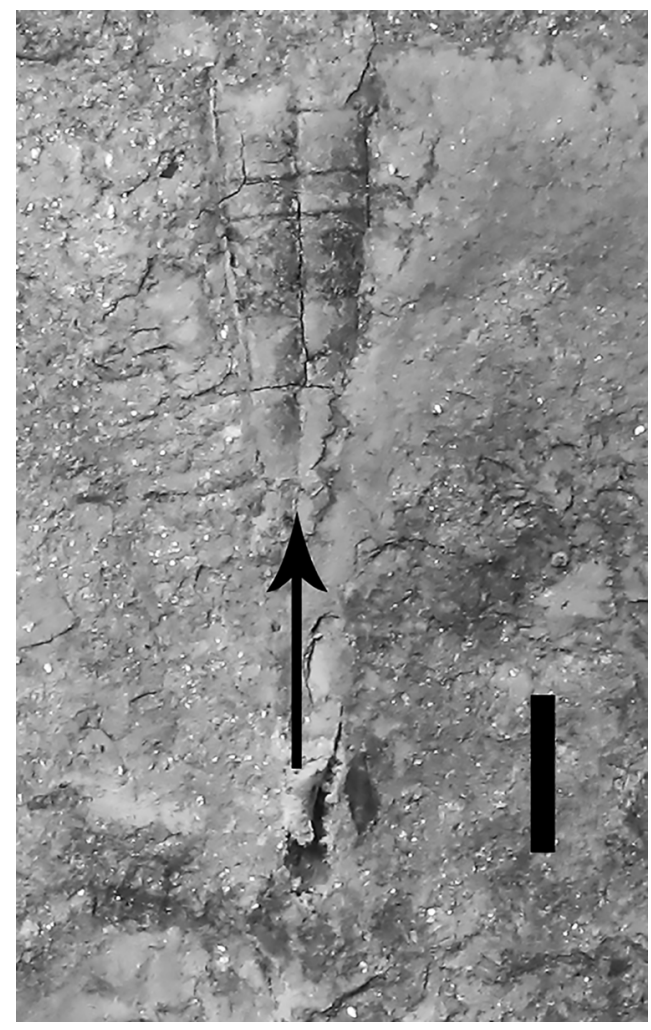

Figure 5. Tentaculites sample (UFPR $0119 \mathrm{PI})$. Note the internal mold with lengthwise fracture. Scale bar $=3 \mathrm{~mm}$.

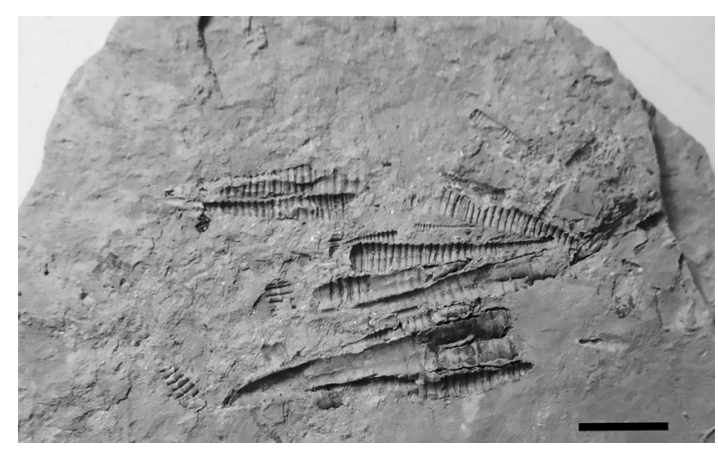

Figure 6. Sample UFPR 0120 PI, Aeroporto Sant'Ana outcrop, São Domingos Member. Note the orientation shown by the external molds. Scale bar $=5 \mathrm{~mm}$. 


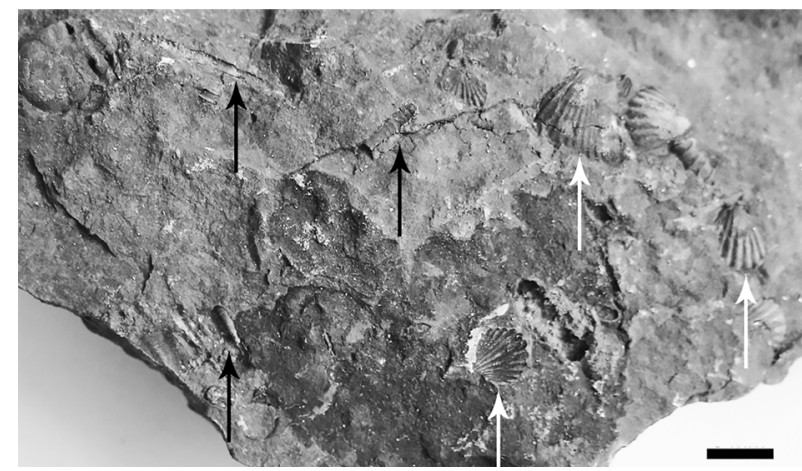

Figure 7. Sample UFPR $0121 \mathrm{PI}$. Tentaculitoids (black arrows) and articulated brachiopods Australocoelia (white arrows). Scale bar $=5 \mathrm{~mm}$.

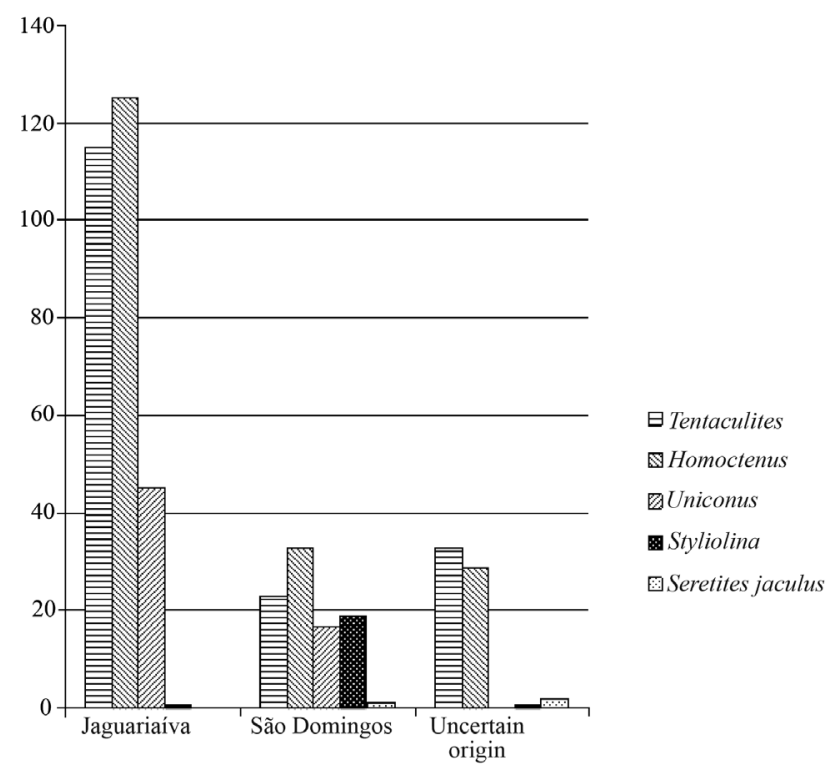

Figure 8. Classification of the tentaculitoid samples deposited on the collection of the Paleontology Laboratory (LabPaleo), Sector of Earth Sciences, at UFPR. Homoctenus is the most common genus in both members.

Table 1. Data from figure 8.

\begin{tabular}{lccc}
\hline Taxon\Member & Jaguariaíva & São Domingos & Uncertain origin \\
\hline Tentaculites & 115 & 23 & 33 \\
Homoctenus & 125 & 33 & 29 \\
Uniconus & 45 & 17 & 0 \\
Styliolina & 1 & 19 & 1 \\
Seretites jaculus & 0 & 1 & 2 \\
Unidentified & 491 & 530 & 417 \\
\hline Total specimens & 777 & 623 & 482 \\
\hline
\end{tabular}

\section{CONCLUSIONS}

The predominant genus in both members, Jaguariaíva and São Domingos, is Homoctenus. There are more tentaculitoid samples from the Jaguariaíva Member than São Domingos, nevertheless this observation can represent a sampling bias, as the material studied here was collected by different student groups during several trips to the field and without exact stratigraphic data. Additionally, some outcrops may have been more often visited than others. Finally, many specimens could not be identified due to their poor preservation.

Considering that tentaculitoids were extinct in the Lower Carboniferous, the studied samples from Devonian of Paraná Basin represent one of the latest representatives of these organisms in the world.

This research recognized that data record from such samples, especially those collected before 90 decade, was incomplete. The only data registered are that the samples belong to Paraná State and Ponta Grossa Formation. This fact prevents detailed studies with 482 specimens, primarily because of lack of exact stratigraphic age. To prevent this problem, more strict procedures to catalog the specimens in the Paleontology Laboratory were adopted.

The samples described in this work are important for further paleontological, taphonomic, biostratigraphic, phylogenetic and taxonomic studies on Paraná Basin. As long as the newest Brazilian publications concerning tentaculitoids are from the 80 's, this paper also contributes to extend the database available to those possible molluscs.

\section{ACKNOWLEDGMENTS}

We are grateful to C.V. Pinto-Coelho for the valuable support and encouragement. J.S. Soares and G.M. da Cruz, for the academical and motivational aid. To PET-Geology Group, MEC, SeSU and CAPES for the opportunity to conduce the research. We also thank the Geology Department (UFPR) for technical support.

\section{REFERENCES}

Alberti, G.K.B. 1982. Dacryoconarids and correlation of LowerMiddle Devonian boundary beds between the Eifel area and the Hartz-Rhenish Slate Mountains-Bohemia-North Africa areas. Newsletters on Stratigraphy, 11:17-21.

Alberti, G.K.B. 1993. Dacryoconaride und homoctenide Tentaculiten des Unter und MittelDevons. Courier Forschungsinstitut Senckenberg, 158:1-229.

Alberti, G.K.B. 2000. Planktonische Tentakuliten des Devon. IV. Dacryoconarida Fisher 1962 aus Unter-Devon. Palaeontographica A, 254:1-23.

Azevedo, I.; Bolzon, R.T. \& Scheffler, S.M. 2002. Roteiro Paleontológico do Devoniano do Estado do Paraná. In: SIMPÓSIO DE ROTEIROS GEOLÓGICOS DO PARANÁ, 1, 2002. Resumos, Ponta Grossa, UEPG \& SBG PR, p. 35-41.

Azevedo-Soares, H.L.C. 1999. Classe Tentaculida na Formação Ponta Grossa: uma proposta de sistematização. Universidade do Estado do Rio de Janeiro, Dissertação de Mestrado, 144 p.

Blind, W. 1969. Die systematische Stellung der Tentaculiten. Palaeontographica A, 133:101-145.

Bond, D. 2006. The fate of the homoctenids (Tentaculitoidea) during the Frasnian-Famennian mass extinction (Late Devonian). Geobiology, 4:167-177. doi: 10.1111/j.1472-4669.2006.00078.x

Bosetti, E.P.; Grahn, Y.; Horodyski, R.S.; Mauller, P.A.; Breuer, P. \& Zabini, C. 2011. An earliest Givetian "Lilliput Effect" in the Paraná Basin, and the collapse of the Malvinokaffric shelly 
fauna. Palaontologische Zeitschrift, 85:49-65. doi 10.1007/ s12542-010-0075-8

Bosetti, E.P.; Peyerl, D.; Horodyski, R.S. \& Zabini, C. 2007. Formação Ponta Grossa: História, fácies e fósseis. In: SIMPÓSIO DE PESQUISA EM ESNINO E HISTÓRIA DE CIÊNCIAS DA TERRA, 1, 2007. Resumos expandidos, Campinas, UNICAMP, p. 353-360.

Brassel, G.; Kutscher, F. \& Stümer, W. 1971. Erst Funde von Weichteilen und Fangarmen bei Tentaculiten. Beiträge zur Sedimentation Fossilfuhrung des Husrückschiefer. Abhandlungen des Hessischen Landesamtes für Bodenforschung, 60:44-50.

Ciguel, J.H.G. 1989. Bioestratigrafia dos Tentaculitoidea no Flanco Oriental da bacia do Paraná e sua ocorrência na América do Sul (Ordiviciano-Devoniano). Instituto de Geociências, Universidade de São Paulo, Dissertação de Mestrado, 237 p.

Ciguel, J.H.G.; Rösler, O. \& Camineiro, D. 1984. Tentaculitoidea da Formação Ponta Grossa no estado do Paraná. In: CONGRESSO BRASILEIRO DE GEOLOGIA, 33, 1984. Anais, Rio de Janeiro, SBG, p. 655-669.

Ciguel, J.H.G.; Rösler, O. \& Hofmeister, R.M. 1987. Preservacão parcial da concha de Tentaculites crotalinus, da Formação Ponta Grossa (Devoniano). Boletim IG-USP. Série Cientifica, 18:17-26.

Fisher, D.W. 1962. Small conoidal shells of uncertain affinities. In: R. Moore (ed.) Treatise on Invertebrate Paleontology, Geological Society of America, p. 102-116.

Grahn, Y.; Mauller, P.M.; Breuer, P.; Bosetti, E.P.; Bergamaschi, S. \& Pereira, E. 2010. The Furnas/Ponta Grossa contact and the age of the lowermost Ponta Grossa Formation in the Apucarana Sub-Basin (Paraná Basin, Brazil): integrated palynological age determination. Revista Brasileira de Paleontologia, 13:89-102. doi: $10.4072 / r b p .2010 .2 .02$

Hajlasz, B. 1967. Eifelskie tentakulity z Gör Swtetokrzysklch i Wytyny Krakowsko-Czesto-chowskiej. Kwartalnik Geologiczny, 11:547-556.

Larsson, K. 1979. Silurian Tentaculitids from Gotland and Scania. Fossils and Strata, 11:1-238.

Li, Y.X. 2000. Fammenian Tentaculitids of China. Journal of Paleontology, 74:969-975.

doi: 10.1666/0022-3360(2000)074<0969:FTOC $>2.0 . C O ; 2$.

Ljaschenko, G.P. 1955. Novye dannye o sistimatike tentakulitov, novakiyi i stiliolii. Biulleten Moskovskogo Obschestva Ispytatelei Prirody, Otdel Geologichskii. Novaia Seriia, 30:94-95.

Ljaschenko, G.P. 1957. Novye roda devonskich tentakulitov. Doklady Akademii nauk SSSR, 116:141-144.

Mendes, J.C. 1965. Introdução à Paleontologia. São Paulo, Companhia Editora Nacional, 382 p.

Milani, E.J.; França, A.B. \& Schneider, R.L. 1994. Bacia do Paraná. Boletim de Geociências da Petrobras, 8:69-82.

Milani, E.J.; Melo, J.H.G.; Souza, P.A.; Fernandes, L.A. \& França, A.B. 2007. Bacia do Paraná. Boletim de Geociências de Petrobras, 15:265-287.
Raup, D.M. \& Stanley, J.M. 1978. Principles of Paleontology. San Francisco, W.H. Freeman, 481 p.

Schenk, E.T. \& McMasters, J.H. 1956. Procedure in Taxonomy. California, Stanford University Press, 115 p.

Simpson, G.G. 1962. Principles of Animal Taxonomy. Columbia, Columbia University Press, $210 \mathrm{p}$.

Towe, K.M. 1978. Tentaculites: evidence for brachiopod affinity? Science, 210:626-628. doi: 10.1126/science.201.4356.626

Vinn, O. 2010. Adaptive strategies in the evolution of encrusting tentaculitoid tubeworms. Palaeogeography, Palaeoclimatology, Palaeoecology, 292:211-221. doi:10.1016/j.palaeo.2010.03.046

Vinn, O.; Hove, H.A.T.; Mutvei, H. \& Kirsimae, K. 2008. Ultrastructure and mineral com-position of serpulid tubes (Polychaeta, Annelida). Zoological Journal of the Linnean Society London, 154:633-650. doi:10.1111/j.1096-3642.2008.00421.x

Vinn, O. \& Mutvei, H. 2005. Observations on the morphology, and affinities of cornulitids from the Ordovician of Anticosti Island and the Silurian of Gotland. Journal of Paleontology, 79:726-737. doi:10.1666/0022-3360(2005)079[0726:OOTM AA]2.0.CO;2

Vinn, O. \& Mutvei, H. 2009. Calcareous tubeworms of the Phanerozoic. Estonian Journal of Earth Sciences, 58:286-296. doi:10.3176/earth.2009.4.07

Vinn, O. \& Taylor, P.D. 2007. Microconchid tubeworms from the Jurassic of England and France. Acta Palaeontologica Polonica, 52:391-399.

Vinn, O. \& Zatoń, M. 2012. Phenetic phylogenetics of tentaculitoids - extinct problematic calcareous tube-forming organisms. $G F F$, 134:145-156. doi:10.1080/11035897.2012.669788

Weedon, M.J. 1990. Shell structure and affinity of vermiform 'gastropods'. Lethaia, 23:297-309. doi: 10.1111/j.15023931.1990.tb01455.x

Weedon, M.J. 1991. Microstructure and affinity of the enigmatic tubular fossil Trypanopora. Lethaia, 24:227-234. doi: 10.1111/ j.1502-3931.1991.tb01471.x

Wei, F.; Gong, Y. \& Yang, H. 2012. Biogeography, ecology and extinction of Silurian and Devonian tentaculitoids. Palaeogeography, Palaeoclimatology, Palaeoecology, 358360:40-50. doi:10.1016/j.palaeo.2012.07.019

Wittmer, J.M. \& Miller, A.I. 2011. Dissecting the global diversity trajectory of an enigmatic group: the paleogeographic history of tentaculitoids. Palaeogeography, Palaeoclimatology, Palaeoecology, 312:54-65. doi:10.1016/j.palaeo.2011.09.009

Zatón, M. \& Taylor, P.D. 2009. Microconchids (Tentaculita) from the Middle Jurassic of Poland. Bulletin of Geosciences, 84:653-660. doi:10.3140/bull.geosci.1167

Received in October, 2014; accepted in March, 2015. 
Appendix 1. Studied samples from the Ponta Grossa Formation.

Jaguariaíva Member

Genus

Homoctenus

Tentaculites

Styliolina

Uniconus

Not identified

São Domingos Member

Taxon

Homoctenus

Tentaculites

Styliolina

Uniconus

Seretites jaculus

Not identified

Uncertain origin

Taxon

Homoctenus

Tentaculites

Seretites jaculus

Styliolina

Uniconus

Not identified
Samples

NR 0992; NR 0994; NR 1011; NR 1016; NR 1025; NR 2223; NR 2637; NR 3253; NR 3562; NR 3769; NR 3800; NR 4287; NR 5446A; NR 5466; NR 5492; NR 5790; NR 5793; NR 5983B; NR 6051; NR 6051; NR 6057; NR 6060; NR 6115; NR 6116; NR 6372; NR 6434; NR 6435; NR 6458; NR 6476; NR 6478; NR 6489A; NR 6497; NR 6560; NR 6589A; NR 7083B; NR 7094; NR 7095; NR 7137; NR 7140; NR 7173; NR 7178; NR 7193; NR 7209; NR 7306; NR 7335; NR 7341; NR 7364; NR 7391B; NR 7392; NR 7395A; NR 7395C; NR 7403; NR 7420; NR 7421C; NR 7426C; NR 7463; NR 7470; NR 7475; NR 7481; UFPR 0115 PI; UFPR 0125 PI.

NR 0991; NR 0994; NR 1007; NR 3302A; NR 3302B; NR 3726A; NR 3726B; NR 3769; NR 3800; NR 4784; NR 6489B; NR 7083A; NR 7093; NR 7094; NR 7172A; NR 7172B; NR 7223; NR 7257; NR 7366; NR 7395C; NR 7426A; NR 7426E; NR 7428; NR 7461; NR 7463; NR 7467; NR 7468; NR 7473; NR 7474; NR 7476; NR 7477; UFPR 0111 PI; UFPR 0113 PI.

NR 6051.

NR 0990; NR 1005; NR 1010; NR 3338A; NR 3338B; NR 3726B; NR 5251; NR 5466; NR 6057; NR 6345; NR 6435; NR 6477; NR 6478; NR 6480; NR 6495; NR 6515A; NR 6561; NR 7096; NR 7097; NR 7098; NR 7138; NR 7139; NR 7140; NR 7153; NR 7273; NR 7335; NR 7346; NR 7391A; NR 7395A; NR 7420; NR 7425A; NR 7425B; NR 7426A.

NR 0993; NR 0994; NR 0998; NR 1000; NR 1001; NR 1002; NR 1008; NR 1009; NR 1012; NR 1014A; NR 1016; NR 1024; NR 1027; NR 1030; NR 2636; NR 2637; NR 3358; NR 3405; NR 3691; NR 3726B; NR 3769; NR 3800; NR 4287; NR 4843; NR 5270; NR 5435; NR 5446A; NR 5464; NR 5466; NR 5492; NR 5492; NR 5566; NR 5733; NR 5783; NR 5784; NR 5785; NR 5788; NR 5790; NR 5792; NR 5793; NR 5793; NR 5794; NR 5795; NR 5833; NR 6051; NR 6051; NR 6057; NR 6060; NR 6115; NR 6116; NR 6371; NR 6373; NR 6435; NR 6479; NR 6487; NR 6497; NR 6515A; NR 6562; NR 6603; NR 6604; NR 6868B; NR 7068B; NR 7138; NR 7139; NR 7153; NR 7182; NR 7189; NR 7198A; NR 7198B; NR 7246; NR 7306; NR 7307; NR 7335; NR 7340; NR 7341; NR 7391A; NR 7391A; NR 7395A; NR 7395B; NR 7395C; NR 7403; NR 7420; NR 7421A; NR 7421A; NR 7421B; NR 7425B; NR 7425C; NR 7425D; NR 7426E; NR 7460; NR 7462; NR 7463; NR 7464; NR 7465; NR 7466; NR 7469; NR 7471; NR 7472; NR 7475; NR 7477; NR 7479; NR 7480; NR 7482; NR 7483; NR 7484; NR 7485; NR 7486; UFPR 0121 PI.

Samples

NR 2507; NR 3747; NR 4473B; NR 6411; NR 6510; NR 6669A; NR 6669B; NR 6699; NR 6762; NR 6770B; NR 6781B; NR 6288; NR 1772; NR 6859; NR 6859; NR 6151; NR 5954A; NR 5954B; NR 6139; NR 5282; UFPR 0120 PI.

NR 6244; NR 6669A; NR 6767; NR 6771; NR 6772A; NR 6772B; NR 6698; UFPR 0119 PI.

NR 4473B; NR 6244; NR 6520; NR 6770A; NR 6771; NR 6772A.

NR 3747; NR 3747; NR 5720; NR 5914; NR 6559; NR 6779; NR 999; NR 3395B; NR 3395A; UFPR 0116 PI.

UFPR 0114 PI.

NR 2507; NR 3564; NR 5311; NR 5447; NR 5561; NR 5779; NR 5907; NR 5908; NR 5909; NR 5912; NR 5913; NR 5914; NR 6170A; NR 6170B; NR 6174; NR 6228; NR 6229; NR 6230; NR 6231; NR 6411; NR 6510; NR 6521; NR 6545A; NR 6545B; NR 6713 NR 6744; NR 6762; NR 6767; NR 6770A; NR 6770B; NR 6772A; NR 6781; NR 6782A; NR 6956; NR 6859; NR 2509; NR 6720; NR 6139; NR 5061; NR 5432.

Samples

NR 2118; NR 1989; NR 1632A; NR 1632B; NR 1672B; NR 1879; NR 1888; NR 1890; NR 1949; NR 2020; NR 2350A; NR 2350E; NR 2350H; NR 3467; NR 3552; NR 3627A; NR 4614; NR 4627; NR 4628; NR 4722; NR 4843; NR 6030; NR 6055; NR 7458; NR 7459.

NR 0997; NR 1735; NR 1751; NR 1873; NR 1874; NR 1885; NR 1892; NR 1949; NR 2115; NR 2350D; NR 2978; NR 3551; NR 4614; NR 4627; NR 4628; NR 4722; NR 6030; NR 6055; NR 7457; NR 7459.

NR 1689; NR 2350C.

NR 3551; UFPR 0117 PI.

NR 1887.

NR 1989; NR 4363; NR 6217; NR 6218; NR 6218; NR 1632A; NR 1686; NR 1689; NR 1735; NR 1751; NR 1787; NR 1873; NR 1876; NR 1877; NR 1878; NR 1880; NR 1882; NR 1883; NR 1886; NR 1887; NR 1889; NR 1899; NR 1900; NR 1906; NR 1907; NR 1942; NR 1942; NR 1947; NR 1951; NR 2020; NR 2022; NR 2027; NR 2113; NR 2114; NR 2350A; NR 2350B; NR 2350C; NR 2350D; NR 2350E; NR 2350G; NR 2350H; NR 2642; NR 3467; NR 3627B; NR 4613; NR 4614; NR 4620; NR 4622; NR 4627; NR 4628; NR 4722; NR 5118; NR 5187; NR 5289; NR 5421; NR 6030; NR 7052; NR 7053; NR 7456; NR 7457; NR 7459; UFPR 0112 PI. 